\title{
Tanggung Jawab Produsen Rokok terhadap Bahaya Rokok Menurut Undang-Undang Nomor 8 Tahun 1999 tentang Perlindungan Kosumen dan Undang-Undang Nomor 36 Tahun 2009 tentang Kesehatan
}

\author{
Ryan \\ (Mahasiswa Program S1 Fakultas Hukum Universitas Tarumanagara) \\ (Email : ryansetio@gmail.com)
}

\section{Ermanto Fahamsyah}

(Corresponding Author)

(Dosen Fakultas Hukum Univesitas Jember, Meraih Sarjana Hukum dari Fakultas Hukum Universitas Jember (2002), Magister Hukum dari Fakultas Hukum Universitas Indonesia (2008), Doktor Ilmu Hukum dari Fakultas Hukum Universitas Indonesia (2013)

(Email : ermanto_fahamsyah@yahoo.co.id)

\begin{abstract}
Consumer Protection Law regulates the legal protection of consumers and is intended to regulate the responsibilities and obligations of business actors / producers. However, there are still a number of producers who in carrying out business activities that still violate the provisions in the UUPK, one of which is cigarette producers. Therefore, the author propose a problem about how cigarette manufacturers' responsibility for the dangers of cigarettes according to the Consumer Protection Law and the Health Law. The author examines the problem by using normative legal research methods that use secondary data. From the results of the study concluded that the responsibility of cigarette producers to the dangers of cigarettes according to the Consumer Protection Law and the Health Law is that cigarette producers must be responsible for providing compensation in the form of bearing medical expenses for diseases caused by cigarettes themselves and providing honest, clear and correct information about the product, and change the results of the product to be in accordance with the standard quality of goods and / or services that already exist.
\end{abstract}

Keywords: Consumer Protection, Liability, Cigarette. 


\section{PENDAHULUAN}

\section{A. Latar Belakang}

Indonesia merupakan negara hukum, yang dalam merumuskan prinsip perlindungan hukumnya berlandaskan Pancasila. Pancasila sebagai ideologi dan falsafah negara merupakan bagian dari Pembukaan Undang-Undang Dasar Negara Republik Indonesia Tahun 1945 (UUD Tahun 1945). Dimana dalam pembukaan UUD Tahun 1945 Alinea ke-4 terdapat kata "perlindungan" yang menjadi dasar dari perlindungan hukum di Indonesia.

Berbicara menganai perlindungan hukum, menurut Satjipto Rahardjo, "Perlindungan hukum adalah upaya melindungi kepentingan seseorang dengan cara mengalokasikan suatu kekuasaan kepadanya untuk bertindak dalam kepentingannya memberikan perlindungan (pengayoman) kepada masyarakat. Oleh karena itu, perlindungan hukum terhadap masyarakat tersebut harus diwujudkan dalam bentuk adanya kepastian hukum. ${ }^{1}$

Salah satu bentuk perlindungan hukum yang ada di Indonesia adalah Hukum Perlindungan Konsumen. Hukum perlindungan konsumen ini diciptakan untuk melindungi dan memenuhi kebutuhan konsumen, Perlindungan konsumen berbicara mengenai jaminan atau kepastian tentang terpenuhinya hak-hak konsumen ${ }^{2}$ Perlindungan konsumen di Indonesia diawali dengan dikeluarkannya Undang-Undang Nomor 10 Tahun 1961 tentang Barang lalu diikuti dengan berdiri nya YLKI (Yayasan Lembaga Konsumen Indonesia) pada tahun 1973.

Perkembangan peraturan perundang-undangan dalam bidang perlindungan konsumen dapat pula dilihat pada hasil inventarisasi peraturan perundang-undangan yang dilakukan dalam rangka penyususan rancangan akademik undang-undang tentang perlindungan

\footnotetext{
${ }^{1}$ Satjipto Raharjo, Permasalahan Hukum di Indonesia, (Bandung: Alumni, 1983), hal. 121.

${ }^{2}$ Janus Sidabalok, Hukum Perlindungan Konsumen di Indonesia, (Bandung: Citra Aditya Bakti, 2006), hal. 10 .
} 
konsumen. ${ }^{3}$ Hasil inventarisasi tersebut dibagi dalam 8 bidang, yaitu: bidang kesehatan dan obat-obatan, makanan dan minuman, alat-alat elektronik, kendaraan bermotor, metrologi dan tera, industri, pengawasan mutu barang dan lingkungan hidup. ${ }^{4}$ Sebagai perkembangan terakhir dan sangat berarti adalah dengan lahirnya Undang-Undang Perlindungan Konsumen, yang merupakan pengikat dari berbagai ketentuan perundang-undangan di bidang perlindungan konsumen. ${ }^{5}$

Pengertian perlindungan konsumen telah diatur dalam Undang-Undang Nomor 8 Tahun 1999 tentang Perlindungan Konsumen (selanjutnya disebut UUPK) adalah sebagai berikut: "Perlindungan Konsumen adalah segala upaya yang menjamin adanya kepastian hukum untuk memberi perlindungan kepada konsumen”.

Seperti yang kita ketahui bahwa kebutuhan dasar manusia adalah sandang, papan, dan pangan. Pangan termasuk kebutuhan manusia yang paling dasar dan sangat penting dalam kehidupan manusia. Oleh karena itu pemerintah harus memperhatikan pengedaran pangan di kalangan masyarakat.

Pengertian Pangan dilihat sesuai dengan Pasal 1 ayat (1) Undang-Undang Nomor 18 Tahun 2012 tentang Pangan (selanjutnya disebut UU Pangan) adalah segala sesuatu yang berasal dari sumber hayati produk pertanian, perkebunan, kehutanan, perikanan, peternakan, peraian, dan air, baik yang diolah maupun tidak diolah yang diperuntukkan sebagai makanan atau minuman bagi konsumsi manusia, termasuk bahan tambahan pangan, bahan baku pangan, dan bahan lainnya yang digunakan dalam proses penyimpanan, pengolahan, dan/atau pembuatan makanan atau minuman.

Setiap produk pangan yang diedarkan di Indonesia harus mencantumkan informasi yang benar dan jelas, tanpa adanya informasi tersebut konsumen akan mengalami kesulitan dalam menentukan produk mana yang akan dibeli. Informasi yang dimaksud diatur dalam Pasal 96 ayat (2) UU Pangan adalah asal, keamanan, mutu, kandungan didalamnya, dan keterangan lain yang diperlukan. Informasi ini dapat

\footnotetext{
${ }^{3}$ Ahmadi Miru, Prinsip-Prinsip Perlindungan Hukum Bagi Konsumen Di Indonesia, Cetakan ke-2, (Jakarta: PT. RajaGrafindo Persada, 2013), hal. 67.

${ }^{4}$ Ibid., hal. 67.

${ }^{5}$ Ibid., hal. 67.
} 
disampaikan dengan berbagai cara, salah satunya dengan mencamtumkan label pangan pada kemasan produk pangan tersebut.

Rokok adalah hasil olahan tembakau termasuk cerutu atau bentuk lainnya yang dihasikan dari tanaman Nicotiana Tabacum, Nicotiana Rustica dan species lainnya atau sintesisnya yang mengandung nikotin dan tar dengan atau tanpa bahan tambahan. Merokok adalah menghisap asap tembakau yang dibakar ke dalam tubuh dan menghembuskannya kembali keluar. ${ }^{6}$ Asap rokok selain merugikan diri sendiri juga dapat berakibat fatal bagi orang-orang lain yang berada di sekitarnya. ${ }^{7}$ Perilaku merokok adalah sesuatu yang dilakukan seseorang berupa membakar dan menghisanya serta menimbulkan asap yang dapat terhisap oleh orang-orang sekitarnya. ${ }^{8}$

Seperti yang kita ketahui bahwa setiap 1 batang rokok mengandung lebih dari 4.000 jenis bahan kimia, beberapa diantaranya bersifat racun, beberapa lainnya dapat merubah sel-sel tubuh menjadi ganas. Diantara 4.000 jenis bahan tersebut, ada dua bahan yang menjadi faktor utama dalam rokok yaitu Tar dan Nikotin, karena sangat membahayakan kesehatan dan menyebabkan ketergantungan seseorang pada rokok. Lalu perlu diketahui juga bahwa 400 dari bahan-bahan tersebut dapat meracuni tubuh, sedangkan 43 dari bahan tersebut dapat menyebabkan kanker. ${ }^{9}$ Pada asap rokok juga mengandung Hidrogen Sianida yang merupakan zat beracun yang sangat berbahaya bagi manusia. Menurut Pasal 113 ayat (1) Undang-Undang Nomor 36 Tahun 2009 tentang Kesehatan (selanjutnya disebut UU Kesehatan), "Pengamanan penggunaan bahan yang mengandung zat adiktif diarahkan agar tidak mengganggu dan membahayakan kesehatan perseorangan, keluarga, masyarakat, dan lingkungan”. Pada produk rokok tembakau tidak terdapat informasi mengenai asal, keamanan,

${ }^{6}$ M. Armstrong, Manajemen Sumber Daya Manusia. (Jakarta: Gramedia, 1990), hal. 14.

${ }^{7}$ H. Danusanto, Rokok dan Perokok, (Jakarta: Aksara, 1990), hal. 5.

${ }^{8}$ M.R. Levy, Life and Health, (New York: Random House, 1984), hal. 3.

${ }^{9}$ Liza Elizabet Aula, Stop Merokok (Sekarang atau Tidak Sama Sekali), Cetakan pertama, (Yogyakarta: Garailmu, 2010), hal. 18-19. 
mutu, kandungan zat-zat apa saja didalamnya serta tanggal kadaluarsa sebagaimana telah diatur dalam Pasal 96 UU Pangan.

Ketua Badan Khusus Pengendalian Tembakau, Ikatan Ahli

Kesehatan Masyarakat Indonesia, dan dosen Fakultas Kesehatan

Masyarakat Universitas Indonesia, Widyastuti Soerojo mengatakan bahwa Nikotin memiliki skor tertinggi dalam hal membuat ketergantungan dibandingkan dengan zat adiktif lainnya seperti heroin, kokain, mariyuana, kafein, dan alkhohol. ${ }^{10}$

Rokok merupakan penyebab beberapa jenis penyakit tidak menular antara lain:

1. $90 \%$ penyakit kanker paru pada laki-laki dan $70 \%$ kanker paru pada perempuan;

2. 56-80\% penyakit saluran nafas kronik (termasuk bronchitis kronik dan pneumonia);

3. $22 \%$ penyakit kardiovaskular (termasuk penyakit jantung dan penyakit pembuluh darah lainnya);

4. $50 \%$ impotensi pada laki-laki;

5. Infertilitas pada perempuan (baik perokok aktfi maupun pasif);

6. Pada ibu hamil dapat menyebabkan abortus spontan, dan melahirkan bayi berat lahir rendah, bayi lahir mati, dan berbagai komplikasi melahirkan lainnya;

7. Pada bayi dan anak-anak akan meningkatkan terjadinya infeksi saluran nafas bagian bawah, penyakit telinga tengah, penyalit saluran pernafasan kronik, asma dan kematian bayo mendadak atau Sudden Infant Death Syndrome (SIDS). ${ }^{11)}$

Dalam Pasal 97 ayat (1) UU Pangan, telah dijelaskan bahwa "Setiap orang yang memproduksi pangan di dalam negeri untuk diperdagangkan wajib mencamtumkan label di dalam dan/atau pada kemasan pangan". Tujuan pemberian label itu sendiri telah dicantumkan dengan jelas dalam Pasal 96 ayat (1) UU Pangan, yaitu "Pemberian label pangan bertujuan untuk memberikan informasi yang benar dan jelas kepada masyarakat tentang setiap produk pangan yang dikemas sebelum membeli dan/atau mengonsumsi pangan".

Hak atas informasi mengenai suatu produk merupakan salah satu hak Konsumen yang tercantum dalam Pasal 4 huruf c UUPK.

\footnotetext{
${ }^{10}$ https://www.infodokterku.com/index.php/en/98-daftar-isi-content/data/datakesehatan/214-data-dan-situasi-rokok-cigarette-indonesia-terbaru

${ }^{11}$ https://www.infodokterku.com/index.php/en/98-daftar-isi-content/data/datakesehatan/214-data-dan-situasi-rokok-cigarette-indonesia-terbaru
} 
Namun dapat dilihat dalam keseharian kita masih banyak produk rokok yang tidak mencamtumkan informasi yang benar dan jelas. Ketidakjelasan mengenai informasi ini lah yang merupakan bahaya bagi konsumen, terutama bagi konsumen tidak langsung atau disebut perokok pasif.

Ketidakjelasan mengenai informasi yang terkandung di dalam label dari produsen rokok atau pelaku usaha ini merupakan cacat produk (cacat informasi) dan telah bertentangan dengan kewajiban pelaku usaha yang telah diatur dalam Pasal 7 huruf (b) UUPK, yaitu "Memberikan informasi yang benar, jelas, dan jujur mengenai kondisi dan jaminan barang dan/atau jasa serta memberi penjelasan penggunaan, perbaikan dan pemeliharaan. Informasi mengenai suatu barang menjadi penting bagi konsumen, karena tinggi rendahnya pemahaman konsumen berpengaruh terhadap kejelasan informasi yang tertera dalam kemasan produk tersebut. Maka produk rokok juga belum sesuai dengan ketentuan Pasal 113 ayat (1) UU Kesehatan karena masih membahayakan kesehatan perseorangan, keluarga, masyarakat, dan lingkungan.

Menurut Azas Nainggolan bahwa Industri rokok telah melakukan pelanggaran hukum berupa tindakan tidak memberikan informasi lengkap dan benar tentang komposisi serta akibat yang ditimbulkan oleh rokok produknya. ${ }^{12}$

Dapat dilihat bahwa pelaku usaha telah melanggar UndangUndang Nomor 8 Tahun 1999 tentang Perlindungan Konsumen, Undang-Undang Nomor 36 Tahun 2009 tentang Kesehatan, UndangUndang Nomor 18 Tahun 2012 tentang Pangan, serta Peraturan Pemerintah Nomor 69 Tahun 1999 tentang Label dan Iklan Pangan. Hal ini karena label yang terdapat dalam kemasan rokok tersebut bertentangan dengan peraturan yang berlaku.

Berdasarkan uraian diatas, maka diangkatlah judul penelitian $\begin{array}{lllllll}\text { "Tanggung Jawab Produsen Rokok } & \text { Terhadap Bahaya Rokok } \\ \text { Menurut Undang-Undang Nomor } 8 & \text { Tahun } 1999 \text { tentang }\end{array}$

\footnotetext{
${ }^{12}$ M. Faisal, "Menuntut Perusahaan Rokok Akibat Kecanduan, Mungkinkah?” https://tirto.id/menuntut-perusahaan-rokok-akibat-kecanduan-mungkinkah-cF11. diakses 10 April 2018.
} 


\section{Perlindungan Konsumen dan Undang-Undang Nomor 39 Tahun 2009 Kesehatan".}

\section{B. Perumusan Masalah}

Berdasarkan latar belakang yang telah dikemukakan, maka rumusan masalah yang akan dibahas yaitu, bagaimana tanggung jawab produsen rokok terhadap bahaya rokok menurut UUPK dan UU Kesehatan?

\section{Metode Analisis}

Penelitian hukum adalah suatu proses untuk menemukan aturan hukum, prinsip-prinsip hukum, maupun doktrin-doktrin hukum guna menjawab isu hukum yang dihadapi. ${ }^{13}$ Di dalam melakukan, penelitian hukum, seorang peneliti seyogianya selalu mengaitkannya, dengan arti-arti yang mungkin dapat diberikan pada hukum. Arti-arti tersebut, merupakan pemahaman-pemahaman yang diberikan oleh masyarakat, terhadap gejala yang dinamakan hukum, yang kemudian dijadikan suatu pegangan. ${ }^{14}$

\section{Jenis Penelitian}

Jenis penelitian yang digunakan Penulis dalam penelitian ini adalah Metode Hukum Normatif. Penelitian hukum normatif adalah penellitian terhadap asas-asas hokum. Penelitian terhadap asas-asas hokum dilakukan terhadap kaidah-kaidah hokum, yang merupakan patokan-patokan berperilaku atau bersikap tidak pantas. ${ }^{15}$

\section{Jenis dan Teknik Pengumpulan Data}

Teknik pengumpulan data yang digunakan dalam penelitian ini adalah dengan studi dokumen atau bahan pustaka.

\footnotetext{
2011), hal. 35 .

${ }^{13}$ Peter Mahmud Marzuki, Penelitian Hukum, (Jakarta: Kencana Prenada Media Group,

${ }^{14}$ Soerjono Soekanto, Pengantar Penelitian Hukum, (Jakarta: UI-Press, 2006), hal. 43.

${ }^{15}$ Soerjono Soekanto dan Sri Mamudji, Penelitian Hukum Normatif, (Jakarta: Rajagrafindo Persada, 2006), hal. 62.
} 
Jenis data yang digunakan dalam penelitian ini adalah data sekunder. Data sekunder yang dimaksud bersumber dari bahan pustaka. Sumber Penelitian berasal dari Data Sekunder yang berupa:

a. Bahan hukum primer yaitu bahan hukum mengikat, dalam hal ini adalah peraturan perundang-undangan dan ketentuan peraturan yang berkaitan dengan penulisan penelitian ini;

b. Bahan hukum sekunder yaitu bahan-bahan yang memberikan penjelasan bahan hukum primer, dalam hal ini adalah bukubuku hukum, makalah-makalah hukum, dan Artikel;

c. Bahan Hukum Tersier yakni bahan yang memberikan petunjuk maupun penjelasan terhadap bahan hukum primer dan sekunder. $^{16}$

\section{Pendekatan Penelitian}

Pendekatan yang digunakan dalam penelitian ini adalah pendekatan undang-undang (statute approach) dan pendekatan konseptual (conseptual approach). Pendekatan undang-undang adalah pendekatan yang dilakukan dengan menelaah semua undangundang dan regulasi yang bersangkut paut dengan isu hukum yang sedang ditangani, dikarenakan dalam penelitian ini akan diteliti undang-undang terhadap praktek atau isu hukum yang terkait ${ }^{17}$ dan pendekatan konseptual merupakan pendekatan yang beranjak dari pandangan-pandangan dan doktrin-doktrin di dalam ilmu hukum. ${ }^{18}$

\section{Spesifikasi Penelitian}

Penelitian ini ditujukan untuk mendapatkan saran-saran mengenai apa yang harus dilakukan untuk mengatasi masalahmasalah tertentu, maka penelitian ini dinamakan penelitian preskriptif. ${ }^{19}$ Penelitian ini mempelajari tujuan hukum, nilai-nilai keadilan, validitas aturan hukum, konsep-konsep hukum, dan norma-norma hukum. ${ }^{20}$ Metode penelitian dalam preskriptif aliran berfikir positivisme hukum akan senantiasa menjadikan norma-

\footnotetext{
${ }^{16}$ Soerjono Soekanto dan Sri Mamudji, Penelitian Hukum Normatif Suatu Tinjauan Singkat, (Jakarta: Raja Grafindo Persada, 2009), hal. 13.

${ }^{17}$ Ibid., hal. 133.

18Ibid., hal. 135.

${ }^{19}$ Soerjono Soekanto, Op.Cit., hal. 10.

20Peter Mahmud Marzuki, Op.Cit., hal. 22.
} 
norma positif sebagai sumber utama untuk menjustifikasikan setiap objek permasalahan hukum. $^{21}$

\section{Teknik Analisis Data}

Teknis analisis bahan hukum yang dipergunakan untuk mendapatkan argumentasi akhir yang berupa jawaban terhadap permasalahan penelitian ini adalah Teknik Deskriptif, yaitu pertama peneliti akan memaparkan apa adanya tentang suatu peristiwa hukum atau kondisi hukum, deskripsi diberikan dengan apa adanya tanpa disertai dengan tanggapan atau pendapat pribadi peneliti. ${ }^{22}$

\section{PEMBAHASAN}

\section{A. Fakta Hukum}

1. Fakta Hukum di Indonesia

Rohayani berumur 50 tahun yang melayangkan somasi kepada 2 produsen rokok di Indonesia yaitu Djarum dan Gudang Garam, somasi ini dikirimkan kepada Djarum dan Gudang Garam pada 19 Februari 2018, alasan dilayangkannya somasi tersebut adalah karena Rohayani merasa dirugikan ia mengalami penurunan kualitas hidup serta ia menerima dampak buruk berupa paru-paru berlubang dari aktivitas merokok selama 25 tahun. Kondisi ini membuat ia berkali-kali berobat sejak tahun 2005, namun ia tidak dapat menghentikan aktivitas rokoknya meskipun telah sakit karena sudah kecanduan rokok yang di timbulkan dari kandungan nikotin di dalamnya dan. Rohayani menuntut ganti rugi sebesar Rp 178.074.000 sebagai ganti rugi uang yang dihabiskan untuk membeli produk rokok kepada Produsen Rokok Gudang Garam, dan santunan senilai Rp 500 miliar. Rohayani juga menuntut ganti rugi kepada PT. Djarum Tbk, sebesar Rp 293.068.000, ditambah dengan santunan

\footnotetext{
${ }^{21}$ Sulistyowati Irianto dan Shidarta, Metode Penelitian Hukum Konstelasi dan Refleksi, (Jakarta: Pustaka Obor Indonesia, 2009), hal. 160.

22I Made Pasek Diantha, Metodeologi Penelitian Hukum Normatif Dalam Justifikasi Teori Hukum, (Jakarta: Kencana Prenada Media Group, 2016), hal. 152.
} 
senilai Rp 500 miliar. Menurut Azas Nainggolan bahwa industri rokok telah melakukan pelanggaran hukum berupa tindakan tidak memberikan informasi lengkap dan benar tentang komposisi serta akibat yang ditimbulkan oleh rokok produknya.

2. Fakta Hukum di Mississipi

Di Amerika Serikat, tepat nya di Mississipi juga terdapat upaya penuntutan yang sama kepada perusahaan rokok pada tahun 1994. Yang melawan adalah seorang Jaksa Agung setempat bernama Mike Moore. Mike Moore menuntut 13 perusahaan rokok. Dasar gugatan Mike Moore itu sendiri adalah bahwa perusahaan rokok telah memberikan dampak buruk bagi masyarakat berupa strategi manipulatif untuk menyembunyikan efek kecanduan kandungan nikotin dalam rokok hingga menyebabkan kas daerah Kota Mississipi senilai \$25 miliar tersedot hanya untuk membiayai pengobatan masyarakat yang sakit karena rokok.

Pada saat penyidikan ditemukan lah dokumen perusahaan Brown \& Williamson Tobacco Corporation yang memperlihatkan bahwa perusahaan sebetulnya paham mengenai bahaya dari rokok, namun dirahasiakan oleh pihak perusahaan.

Mike Moore mengatakan bahwa Perusahaan rokok lah yang menyebabkan krisis ini, maka mereka lah yang harus bertanggung jawab. Gugatan Mike Moore dikabulkan oleh Pengadilan Chancery, Jackson County. Pengadilan menetapkan tergugat harus mengganti uang sebesar \$246 miliar untuk mendanai program pencegahan maupun pengendalian bahaya yang ditimbulkan dari rokok.

3. Faktu Hukum di Florida

Kasus penuntutan kepada perusahaan rokok juga pernah dilakukan oleh seorang wanita di Amerika Serikat yang bernama Cynthia Robinson. Cynthia Robinson menuntut kepada perusahaan rokok terbesar kedua di Amerika Serikat yaitu perusahaan rokok bernama RJ Reynolds Tobacco. Cynthia Robinson meminta ganti 
rugi sebesar Rp 236 triliun atas kematian suaminya pada umur 36 tahun yang merupakan perokok karena kanker paru-paru pada tahun 1996. Dalam tuntutannya, Cynthia Robinson beranggapan bahwa kematian suaminya karena kanker paru-paru tidak dapat dilepaskan dari kelalaian RJ Reynolds Tobacco yang tidak memberitahukan bahwa rokok produksi mereka mengandung nikotin yang adiktif serta dapat menyebabkan kanker paru-paru. Cynthia Robinson memenangkan tuntutannya kepada perusahaan RJ Reynolds Tobacco pada tahun 2014 silam. Sidang penuntutan kepada perusahan rokok RJ Reynolds Tobacco berjalan selama hampir empat minggu. Pengadilan Florida akhirnya mengetok palu dan menjatuhkan vonis pada perusahaan rokok RJ Reynolds Tobacco setelah mempertimbangkan berbagai hal termasuk perusahaan rokok dianggap lalai.

\section{B. Analisa}

1. Tanggung Jawab Produsen Rokok Terhadap Bahaya Rokok Menurut Undang Undang Perlindungan Konsumen dan Undang-Undang Kesehatan.

Menurut Kementerian Kesehatan Republik Indonesia Berikut ini data hasil penelitian oleh Riset Kesehatan Dasar tahun 2007 mengenai umur perokok diketahui pada usia 5-9 tahun sebesar 1,2\%, usia 10-14 tahun sebesar $10.3 \%$, usia $15-19$ sebesar $33,1 \%$, usia 20 24 sebesar $12,1 \%$, usia 25-29 tahun sebesar 3,4\%, dan usia $\geq 30$ tahun sebesar $4 \%$. Umur mulai merokok pada perokok mengalami peningkatan berdasarkan data hasil penelitian oleh Riset Kesehatan Dasar tahun 2010, yaitu: pada umur 5-9 tahun sebesar 1,7\% (naik sebanyak 0,5\%), umur 10-14 tahun sebesar $17.5 \%$ (naik sebanyak 5,2\%), umur 15-19 sebesar 43,1\% (naik sebanyak 10,2\%), umur 2024 sebesar 14,6\% (naik sebanyak 2,5\%), usia 25-29 tahun sebesar 
$4,3 \%$ (naik sebanyak $0,9 \%$ ), dan usia $\geq 30$ tahun sebesar $5,3 \%$ (naik sebanyak $1,3 \%)^{23}$

Menurut World Health Organization (WHO) Indonesia menempati urutan ke 3 (tiga) negara dengan jumlah perokok terbanyak, berdasarkan riset yang dilakukan oleh WHO pada tahun 2011, di Indonesia, $67,4 \%$ pria dan 4,5\% wanita (terdiri dari $36,1 \%$ dari populasi) saat ini menghisap rokok.

Sedangkan menurut Global Adult Tobacco Survey (GATS), di Indonesia $67 \%$ laki- laki merupakan perokok dengan tingkat kematian untuk serangan jantung sebesar $81,5 \%$, kanker paru-paru sebesar $84,7 \%$, kelahiran prematur sebesar 49,5\%, stroke sebesar $45,5 \%$, penyakit paru obstruktif kronik sebesar 36\%, dan penyakitpenyakit lainnya yang belum diketahui secara pasti. ${ }^{24}$

Peredaran rokok jika dikaitkan dengan UUPK maka telah melanggar ketentuan yang ada di UUPK, terutama dalam hal hak konsumen. Terhadap konsumen, pelaku usaha dalam memproduksi produk rokok telah melanggar Pasal 4 UUPK, dimana dalam Pasal 4 terdapat hak konsumen untuk mendapatkan keamanan dan keselamatan dalam mengkonsumsi suatu barang barang, hak untuk memilih dan mendapatkan barang sesuai dengan yang dijanjikan, hak untuk menerima informasi yang benar, jelas dan jujur mengenai kondisi barang yang dibeli, serta hak untuk mendapatkan kompensasi, ganti rugi dan/atau penggantian apabila barang yang di terima tidak sesuai dengan yang di perjanjikan atau tidak sebagaimana mestinya. Namun seperti yang diketahui bahwa pada kemasan rokok tidak terdapat informasi yang benar, jelas dan jujur mengenai zat-zat yang terkandung didalamnya.

Bahwa Produk rokok tidak pernah memberikan informasi bahwa ketika seseorang memulai untuk merokok, akan memberikan

\footnotetext{
${ }^{23}$ http://www.depkes.go.id/article/view/18091700002/penguatan-upaya-pengendaliankonsumsi-rokok-sangat-dibutuhkan.html

${ }^{24}$ https://www.tobaccofreekids.org/blog/2012_09_12_indonesia
} 
dampak kecanduan bagi yang menghisapnya, dimana informasi mengenai kecanduan seharusnya diperlihatkan atau ditunjukkan bahkan seharusnya disosialisasikan karena informasi mengenai zat adiktif yang memberikan sifat candu berperan besar dalam hal untuk penurunan konsumen produk rokok.

Pelanggaran yang selanjutnya adalah tentang kewajiban pelaku usaha yang terdapat dalam Pasal 7 UUPK, kewajiban pelaku usaha tersebut ialah: ${ }^{25}$

a. Beritikad baik dalam melakukan kegiatan usahanya;

b. Memberikan informasi yang benar, jelas dan jujur mengenai kondisi dan jaminan barang dan/atau jasa serta memberi penjelasan penggunaan, perbaikan dan pemeliharaan;

c. Memperlakukan atau melayani konsumen secara benar dan jujur serta tidak diskriminatif;

d. Menjamin mutu barang dan/atau jasa yang diproduksi dan/atau diperdagangkan berdasarkan ketentuan standar mutu barang dan/atau jasa yang berlaku;

e. Memberi kesempatan kepada konsumen untuk menguji, dan/atau mencoba barang dan/atau jasa tertentu serta memberi jaminan dan/atau garansi atas barang yang dibuat dan/atau yang diperdagangkan;

f. Memberi kompensasi, gantu rugi dan/atau penggantian atas kerugian akibat penggunaan, pemakaian dan pemanfaatan barang dan/atau jasa yang diperdagangkan;

g. Memberi kompensasi, gantu rugi dan/atau penggantian apabila barang dan/atau jasa yang diterima atau dimanfaatkan tidak sesuai dengan perjanjian.

Dimana dalam pasal 7 UUPK, pelaku usaha diwajibkan untuk beritikad baik dalam melakukan kegiatan usahanya, seperti dalam hal memberikan informasi dengan benar, jelas dan jujur mengenai kondisi barang yang dijualnya, memperlakukan atau melayani konsumen secara benar dan jujur, menjamin mutu barang yang di perdagangkan sesuai dengan standar mutu barang yang berlaku, serta memberikan kompensasi, ganti rugi dan/atau penggantian apa bila Pasal 7.

${ }^{25}$ Indonesia, Undang-Undang Nomor 8 tahun 1999 tentang Perlindungan Konsumen, 
barang yang diterima konsumen tidak sesuai dengan yang di perjanjikan.

Pelanggaran terkait perbuatan yang dilarang bagi pelaku usaha telah di atur dalam pasal 8 sampai dengan pasal 17 UUPK. Namun terkait dengan produksi rokok oleh pelaku usaha, tidak semua pasal terkait dengan perbuatan yang dilarang bagi pelaku usaha dapat di terapkan. Apabila di kaitkan dengan UUPK, dapat ditemukan beberapa pelanggaran, yaitu:

a. Pelaku usaha dilarang memproduksi atau memperdagangkan barang yang tidak memenuhi atau tidak sesuai dengan standar yang di persyaratkan; ${ }^{26}$

b. Pelaku usaha dilarang memperdagangkan barang yang cacat atau tercemar, dengan atau tanpa memberikan informasi secara lenkap dan benar; ${ }^{27}$

c. Pelaku usaha dilarang menawarkan, memproduksi, mengiklankan suatu barang secara tidak benar dan/atau seolah-olah barang tersebut telah memenuhi standar mutu tertentu, barang tersebut dalam keadaan baik dan/atau baru ataupun barang tersebut tidak mengandung cacat tersembunyi. ${ }^{28}$

Produksi rokok oleh pelaku usaha sangat jelas telah merugikan konsumen yang mengkonsumsi baik secara sengaja ataupun tidak sengaja dalam arti perokok pasif. Sebagai bentuk tanggung jawab oleh pelaku usaha, UUPK dalam pasal 19 sampai dengan pasal 28 telah menentukan bentuk tanggung jawab yang dibebankan kepada pelaku usaha yang merugikan konsumen. Adapun bentuk pertanggungjawaban yang terkait dengan produksi rokok adalah pada Pasal 19. Adapun bentuk pertanggungjawaban tersebut ialah:

a. Pelaku usaha bertanggung jawab memberikan ganti rugi atas kerusakan, pemncemaran, dan/atau kerugian konsumen akibat mengkonsumsi barang dan/atau jasa yang dihasilkan arau diperdagangkan;

b. Ganti rugi sebagaimana dimaksud pada ayat (1) dapat berupa penggembalian uang atau penggantian barang dan/atau jasa yang sejenis atau setara nilaina, arau perawaran keseharan dan/atau

\footnotetext{
${ }^{26}$ Ibid., Pasal 8 ayat (1).

${ }^{27}$ Ibid., Pasal 8 ayat (2).

${ }^{28}$ Ibid., Pasal 9 ayat (1).
} 
pemberian santunan yang sesuai dengan ketentuan peraturan perundang-undangan yang berlaku;

c. Pemberian ganti rugi dilaksanakan dalam tenggang waktu 7 (tujuh) hari setelah tanggal transaksi;

d. Pemberian ganti rugi sebagaimana dimaksud pada ayat (1) dan ayat (2) tidak menghapuskan kemungkinan adanya tuntutan pidana berdasarkan pembuktian lebih lanjut mengenai adanya unsur kesalahan;

e. Ketentuan sebagaimana dimaksud pada ayat (1) dan ayat (2) tidak berlaku apabila pelakuusaha dapat membuktina bahwa kesalahan tersebut merupakan kesalahan konsumen. ${ }^{29}$

Ganti rugi sebagai bentuk tanggung jawab pelaku usaha merupakan hak bagi konsumen yang merasa dirugikan oleh pelaku usaha yang tidak beretikad baik. Sebaliknya, menjadi kewajiban bagi pelaku usaha untuk mengembalikan uang konsumen sebagai bentuk ganti rugi, ataupun mengganti barang yang telah dibeli oleh konsumen dengan barang yang selayaknya diperoleh konsumen. Namun bila hal ini tidak dilakukan oleh pelaku usaha, maka konsumen berhak untuk menggugat pelaku usaha/ produsen melalui suatu lembaga yang memiliki tugas untuk menyelesaikan sengketa antara kosumen dan pelaku usaha/produsen ataupun melalui peradilan yang berada di lingkup peradilan umum. Selain sanksi berupa penjara, sanksi pidana ini juga bisa dijatuhkan hukuman tambahan seperti perampasan barang tertentu, pengumuman keputusan hakim, pembayaran ganti rugi, perintah penghentian kegiatan tertentu yang menyebabkan timbulnya kerugian konsumen, kewajiban penarikan barang dari peredaran, atau pencabutan izin usaha. $^{30}$

Produk rokok jika dilihat dalam sisi UU Pangan maka telah melanggar beberapa aturan yang ada, salah satunya dalam pencantuman label. Rokok dapat dikatangan sebagai pangan karena rokok merupakan hasil sumber hayati produk pertanian, perkebunan,

\footnotetext{
${ }^{29}$ Ibid., Pasal 19.

${ }^{30}$ Ibid., Pasal 63.
} 
kehutanan, perikanan, peternakan, peraian, dan air, baik yang diolah maupun tidak diolah. Dalam pencamtuman informasi dapat dilakukan dengan pemberian label, yang dimaksud label dalam Pasal 96 ayat (2) UU Pangan adalah asal, keamanan, mutu, kandungan didalamnya, dan keterangan lain yang diperlukan.

Produksi rokok jika dilihat dari sisi UU Kesehatan tentulah sangat merugikan masyarakat, dalam hal sebagai konsumen menyebabkan ketergantungan oleh zat adiktif yang terdapat dalam rokok dan menurunkan kualitas hidup. Sebagai masyarakat, rokok menjadi salah satu polusi udara, serta membahayakan kesehatan dirinya oleh karena terpapar asap rokok.

Dalam pasal 3 UU Kesehatan dikatakan bahwa Pembangunan kesehatan bertujuan untuk meningkatkan kesadaran, kemauan, dan kemampuan hidup sehat bagi setiap orang agar terwujud derajat kesehatan masyarakat yang setinggi-tingginya, sebagai investasi bagi pembangunan sumber daya manusia yang produktif secara sosial dan ekonomis. ${ }^{31}$ Pelaku usaha dalam memproduksi produk rokok tentu saja telah melanggar ketentuan yang di atur dalam UU Kesehatan, karena menjauhkan amanat dari UU Kesehatan.

Produksi rokok juga secara tidak langsung turut serta dalam pelanggaran Pasal 6 UU Kesehatan yang berisikan "Setiap orang berhak mendapatkan lingkungan yang sehat bagi pencapaian derajat kesehatan". Dalam hal ini, asap rokok yang dihasilkan oleh perokok membuat masyarakat tidak mendapatkan lingkungan yang sehat. Rokok juga melanggar ketentutan pasal 113 UU Kesehatan dalam hal pengamanan penggunaan bahan yang mengandung zat adiktif diarahkan agar tidak mengganggu dan membahayakan kesehatan perseorangan, keluarga, masyarakat, dan lingkungan.

Tanggung jawab pelaku usaha lebih lanjut tidak diatur di dalam UU Kesehatan, namun hanya diatur didalam UUPK. Di dalam UU

\footnotetext{
${ }^{31}$ Indonesia, Undang-Undang Nomor 36 tahun 2009 tentang Kesehatan, Pasal 3.
} 
Kesehatan juga tidak mengatur lebih lanjut mengenai pengamanan bahan yang mengandung zat adiktif, pengaturannya diatur lebih lanjut dalam PP No. 109 Tahun 2012 tentang pengamanan bahan yang mengandung zat adiktif (PP No.109 Tahun 2012).

Di Indonesia terdapat regulasi yang mengatur tentang tembakau, yaitu PP No. 109 tahun 2012 berupa produk tembakau bagi kesehatan, namun regulasi yang disahkan pada tahun 2012 ini menimbulkan pro dan kontra, banyak masyarakat menilai bahwa PP ini pro terhadap produsen rokok, dimana dalam PP ini mengesampingkan peraturan yang lebih tinggi seperti UU Kesehatan dan UUPK serta UU Pangan. Seperti yang kita ketahui bahwa sesuai dengan hirarki peraturan di Indonesia Peraturan Pemerintah seharusnya dibuat dengan tidak bertentangan dengan pertaturan diatasnya.

Namun pada fakta nya PP ini mengesampingkan pertaturan diatasnya, seperti halnya dalam UUPK dimana dalam UUPK Pasal 4 huruf (c) yang mengatur mengenai hak konsumen atas informasi yang benar dan jelas, namun dalam PP ini mengkhususkan produsen rokok untuk mencamtumkan beberapa informasi saja, jelas hanya dengan informasi yang terbatas maka konsumen dapat berpikir bahwa rokok hanya memiliki kandungan dan bahaya seperti yang di cantumkan pada label kemasan. Berhubungan dengan UUPK mengenai hak konsumen atas informasi yang benar dan jelas, informasi tersebut dalam dicantumkan dalam label kemasan yang telah diatur dalam UU Pangan. Dalam kemasan label produk rokok tidak mencamtumkan informasi yang jelas, namun dengan adanya PP ini, maka mengesampingkan juga peraturan tentang label yang diatur dalam UU Pangan. Jika PP ini dikaitkan dengan UU Kesehatan yang mengatur mengenai definisi kesehatan yaitu, keadaan sehat, baik secara fisik, mental, spiritual maupun sosial yang memungkinkan setiap orang untuk hidup produktif 
secara social dan ekonomis. Namun setiap perokok baik aktif maupun pasif cenderung memiliki keadaan yang tidak sehat dan memungkinkan untuk tidak hidup produktif karena memiliki masalah kesehatan. Jelas bahwa produksi rokok itu sendiri telah bertentangan dengan UU Kesehatan karena kandungan dalam rokok sangat berbahaya bagi manusia.

Karena adanya hubungan hukum antara pelaku usaha dengan konsumen, yang menimbulkan permasalahan yaitu kerugian terhadap pihak konsumen yang sedang menggunakan produk tersebut.

Selain itu, sebelum melihat ke permasalahan, harus melihat pembuktian apabila konsumen dirugikan atau tidak, jika konsumen dirugikan maka konsumen berhak menuntut ganti rugi terhadap pihak pelaku usaha, yang dimana adanya hak-hak konsumen yang dilalaikan seperti dalam Pasal 4 Undang-Undang Nomor 8 Tahun 1999 tentang Perlindungan Konsumen sebagai berikut:

1) Hak atas kenyamanan, keamanan dan keselamatan dalam mengkonsumsi barang dan/atau jasa;

2) Hak untuk memilih barang dan/atau jasa serta mendapatkan barang dan/atau jasa tertentu sesuai dengan nilai tukar dan kondisi serta jaminan yang dijanjikan;

3) Hak atas informasi yang benar, jelas, dan jujur mengenai kondisi dan jaminan barang dan/atau jasa;

4) Hak untuk didengar pendapat dan keluhannya atas barang dan/atau jasa yang digunakan;

5) Hak untuk mendapatkan advokasi, perlindungan, dan upaya penyelesaian sengketa perlindungan konsumen secara patut;

6) Hak untuk mendapat pembinaan dan Pendidikan konsumen;

7) Hak untuk diperlakukan atau dilayani secara benar dan jujur serta tidak diskriminatif;

8) Hak untuk mendapatkan kompensasi, ganti rugi dan/atau penggantian, apabila barang dan/atau jasa yang diterima tidak sesuai dengan perjanjian atau tidak sebagaimana mestinya; dan

9) Hak-hak yang diatur dalam ketentuan peraturan perundangundangan lainnya. ${ }^{32}$

Terkait mengenai peredaran rokok di Indonesia, menurut Bapak Agus Sujatno bahwa produk rokok di Indonesia merupakan produk

${ }^{32}$ Op.Cit., Pasal 4. 
legal, namun meskipun produk rokok merupakan produk yang legal di sisi lain produk rokok merupakan produk yang lethal karena mengandung zat adiktif berupa nikotin. Menurut beliau produk yang mengandung zat adiktif seharusnya dilarang peredarannya, namun pada kenyataannya peredaran produk rokok masih masif, iklannya masih masif, bahkan pemasarannya juga masif. Beliau berpendapat bahwa produk-produk yang harus dikendalikan adalah produkproduk yang kena cukai, seperti halnya minuman keras, senjata, termasuk juga produk rokok. Artinya adalah barang-barang tersebut dalam pemakaiaannya dapat menimbulkan dampak buruk atau negatif bagi masyarakat atau lingkungan hidup maka dari itu konsumsinya perlu dikendalikan, peredarannya perlu di awasi, dan dibebankan biaya yang mahal. Namun beda halnya dengan produk rokok, pada produk rokok tidak ada larangan penjualan rokok. Menurut Bapak Agus Sujatno penjualan produk rokok dimana-mana sangat strategis dan mudah, seperti halnya di minimarket produk rokok dipaparkan di depan kasir, terdapat banyak penjual yang menjual produk rokok secara ketengan/satuan. Tidak adanya regulasi yang melarang produk tersebut untuk peredarannya lah yang menjadi alasan mengapa produk rokok mudah di dapatkan dimana-mana. Berbicara mengenai produk rokok jika dikaitkan dengan UUPK tentu sangat bertolak belakang, karena hak konsumen menurut pasal 4 huruf (c) UUPK menyatakan bahwa konsumen berhak atas informasi yang benar, jelas, dan jujur mengenai kondisi dan jaminan barang dan/atau jasa. Namun informasi tersebut tidak terdapat dalam produk rokok. Produk rokok tidak pernah memberikan informasi bahwa ketika seseorang memulai untuk merokok, akan memberikan dampak kecanduan bagi yang menghisapnya. Terkait mengenai Peraturan Pemerintah Nomor 109 tahun 2012, menurut Bapak Agus bahwa peraturan tersebut merupakan turunan dari UU Kesehatan dimana iklan rokok masih diperbolehkan asalkan sesuai dengan 
ketentuan-ketentuan yang telah diatur didalamnya, berbeda dengan minuman keras yang dilarang periklanannya. Sedangkan regulasi turunan dari UU Kesehatan berupa PP Nomor 109 tahun 2012, menurut beliau bahwa beberapa regulasi atau undang-undang di Indonesia yang mengatur mengenai produk rokok diduga dengan kuat di intervensi oleh industri rokok. Seperti halnya dalam hilangnya pasal 113 ayat (2) UU Kesehatan ketika disahkan pada 14 September 2009, bahwa pada saat sidang paripurna pasal tersebut masih berisikan 3 ayat, namun pada saat UU tersebut dikirimkan ke Presiden untuk ditandatangani, pasal 113 tersebut hanya memiliki 2 ayat. Beliau menambahkan bahwa negara-negara di Kawasan Asia Tenggara telah melarang total iklan tembakau, baik di media cetak, televisi, radio, film dan semacamnya, kecuali di Indonesia. Beliau menambahkan bahwa persentasi kenaikan usia perokok di Indonesia dikarenakan oleh masih adanya iklan mengenai rokok di luar dan di dalam media, berbicara mengenai iklan produk rokok di Indonesia khususnya di televisi, menurut beliau bahwa produk rokok yang mempengaruhi penurunan derajat kesehatan menampilkan iklan yang bersifat membohongi publik karena pada iklan tersebut menampilkan sesuatu yang bersifat macho, gentleman, seolah-olah dengan mengkonsumsi produk tersebut dapat menjadi enerjik dan sehat. Terdapat peraturan bahwa produsen rokok dilarang untuk mencantumkan merek rokoknya, namun seperti yang diketahui bahwa merek rokok yang ada di Indonesia sama dengan nama pabrik produsen rokok tersebut. Mengenai tulisan pada kemasan rokok, yaitu kata mild, light, ultra mild, super premium memberikan makna bahwa rokok tersebut lebih aman untuk dikonsumsi. Menurut Bapak Agus Sujatno, bahwa benar industri rokok menyumbang pajak yang besar kepada negara, namun berbicara mengenai masyarakat yang dirugikan oleh karena asap rokok atau lebih tepatnya disebut perokok pasif bahwa pengeluaran negara yang dibutuhkan untuk 
biaya perawatan masyarakat yang dirugikan oleh rokok lebih besar daripada pendapatan negara yang diberikan oleh industri rokok. YLKI berpendapat bahwa seharusnya industri rokok lah yang memberikan biaya pengobatan kepada masyarakat karena kerugian yang ditimbulkan merupakan akibat dari produk yang di produksinya, namun pihak industri rokok selalu mengelak dengan alasan bahwa penyakit-penyakit yang dialami oleh masyarakat tidak $100 \%$ merupakan akibat dari produk rokok tersebut.

Terkait mengenai produsen rokok dalam memproduksi hasil produksinya harus memenuhi peraturan yang telah ditetapkan. Rokok seperti yang kita ketahui bahwa merupakan hasil olahan pangan berupa daun tembakau, dimana didalam rokok berisikan zatzat beracun yang berbahaya bagi manusia, di dalam kemasan rokok hanya tercantumkan kadar nikotin dan tar namun perlu diketahui bahwa, selain nikotin dan tar, ada sekitar 6.000 bahan kimia lainnya dalam asap rokok dimana 4.000 bahan kimia diantaranya berbahaya bagi kesehatan manusia, sehingga sulit mengetahui komponen mana yang paling menimbulkan risiko kesehatan. Karbon monoksida, nitrogen oksida, dan konstituen gas asap dari hasil pembakaran rokok misalnya, telah terbukti mengurangi transportasi oksigen ke sel, meningkatkan pertumbuhan plak aterosklerotik dalam pembuluh darah, dan membuat platelet darah lengket sehingga membentuk gumpalan.

Peredaran rokok jika dikaitkan dengan UUPK maka telah melanggar ketentuan yang ada di UUPK, terutama dalam hal hak konsumen. Terhadap konsumen, pelaku usaha dalam memproduksi produk rokok telah melanggar Pasal 4 UUPK, dimana dalam Pasal 4 terdapat hak konsumen untuk keamanan dan keselamatan dalam mengkonsumsi barang, hak untuk memilih dan mendapatkan barang sesuai dengan yang dijanjikan, hak untuk menerima informasi yang benar, jelas dan jujur mengenai kondisi barang yang dibeli, serta hak 
untuk mendapatkan kompensasi, ganti rugi dan/atau penggantian apabila barang yang di terima tidak sesuai dengan yang di perjanjikan atau tidak sebagaimana mestinya. Namun seperti yang diketahui bahwa pada kemasan rokok tidak terdapat informasi yang benar, jelas dan jujur mengenai zat-zat yang terkandung didalamnya. Bahwa Produk rokok tidak pernah memberikan informasi bahwa ketika seseorang memulai untuk merokok, akan memberikan dampak kecanduan bagi yang menghisapnya, dimana informasi mengenai kecanduan seharusnya diperlihatkan atau ditunjukkan bahkan seharusnya disosialisasikan karena informasi mengenai zat adiktif yang memberikan sifat candu berperan besar dalam hal untuk penurunan konsumen produk rokok.

Ganti kerugian sebagaimana disebutkan diatas merupakan bentuk tanggung jawab pelaku usaha bagi konsumen yang merasa dirugikan oleh pelaku usaha yang tidak beritikad baik. Sebaliknya, menjadi kewajiban bagi pelaku usaha untuk mengembalikan uang konsumen sebagai bentuk ganti rugi, ataupun mengganti barang yang telah dibeli oleh konsumen dengan barang yang selayaknya diperoleh konsumen.

\section{PENUTUP}

\section{A. Kesimpulan}

Berdasarkan uraian analisis yang telah penulis uraikan pada Bab IV, maka dapat ditarik kesimpulan bahwa tanggung jawab pelaku usaha/produsen rokok jika dikaitkan dengan Pasal 19 UUPK adalah memberikan ganti rugi, pelaku usaha harus memberikan ganti rugi berupa biaya pengobatan kepada perokok aktif maupun perokok pasif yang dalam hal ini perokok pasif lah yang lebih dirugikan, karena secara tidak langsung menghirup asap rokok yang ditimbulkan dari hasil 
pembakaran rokok oleh perokok aktif. Sedangkan UU Kesehatan tidak mengatur lebih lanjut mengenai tanggung jawab pelaku usaha rokok.

\section{B. SARAN}

Bagi pelaku usaha/produsen rokok untuk mencamtumkan informasi secara benar, jelas dan jujur sesuai dengan perarutan yang ada, seperti pencantuman kandungan-kandungan yang ada dalam produk rokok secara menyeluruh dan tidak melebih-lebihkan iklan produk rokok dalam media, membatasi penjualan dengan cara memberikan sanksi kepada pedagang yang menjual produk rokok secara sebarangan seperti menjual produk rokok kepada anak-anak dan menjual secara ketengan, mengurangi kandungan tar dan nikotin dalam tiap produk rokok Bekerja sama dengan pemerintah daerah untuk membuat Kawasan Tanpa Asap Rokok. UU Kesehatan seharusnya mengatur mengenai tanggung jawab berupa sanksi terhadap masyarakat yang tidak memenuhi ketentuan ketentuan dalam UU Kesehatan.

\section{Daftar Pustaka}

\section{A. Buku}

Amirudin dan Zainal Asikin. Pengantar Metode Penelitian Hukum. (Jakarta: Raja Grafindo Persada, 2004).

Anshori, Abdul Ghofur. Filsafat Hukum. (Yogyakarta: Gadjah Mada University Press, 2016).

Aula, Liza Elizabet. Stop Merokok (Sekarang atau Tidak Sama Sekali). Cetakan pertama. (Yogyakarta: Garailmu, 2010).

Bartens, K. Etika. (Jakarta: PT. Gramedia Pustaka Utama, 2001).

Diantha, I Made Pasek. Metodeologi Penelitian Hukum Normatif dalam Justifikasi Teori Hukum. (Jakarta: Kencana Prenada Media Group, 2016). 
Hadjon, Philipus M. Perlindungan Hukum bagi Rakyat Indonesia. (Surabaya: Bina Ilmu, 1987).

Hamzah, Andi. Kamus Hukum. (Jakarta: Ghalia Indoensia, 1986).

Huijbers, Theo. Filsafat Hukum. (Yogyakarta: Kanisius, 1990).

Kansil, CST. Pengantar Ilmu Hukum dan Tata Hukum Indonesia. Cetakan ke-7. (Jakarta: Balai Pustaka, 1986).

Khairunnisa. Kedudukan. Peran dan Tanggung Jawab Hukum Direksi. (Medan: Pasca Sarjana, 2008).

Marinus, Angipora. Dasar-Dasar Pemasaran. (Jakarta: PT. Raja Grafindo Persada, 2002).

Marzuki, Peter Mahmud. Penelitian Hukum. (Kencana Prenada Media Group, Jakarta, 2011).

2014).

- Pengantar Ilmu Hukum. (Jakarta: Kencana,

Mertokusumo, Sudikno. Penemuan Hukum. (Bandung: Citra Aditya Bakti, 2009).

Miru, Ahmadi dan Sutarman Yodo. Hukum Perlindungan Konsumen. Cetakan Ke-2. (Jakarta: Raja Grafindo Persada, 2004).

Miru, Ahmadi. Prinsip-prinsip Perlindungan Hukum bagi Konsumen di Indonesia. Cetakan ke-2. (Jakarta: Rajawali Pers, 2013).

Moleong, Lexy J. Metodologi Penelitian Kualitatif. (Bandung: Remaja Rosdakarya, 2002).

Notoatmodjo, Soekidjo. Etika \& Hukum Kesehatan. Cetakan pertama. (Jakarta: PT. Rineka Cipta, 2010).

Raharjo, Satjipto. Ilmu Hukum. (Bandung: Citra Aditya Bakti, 2000). Ilmu Hukum. cetakan ke-8. (Bandung: PT. Citra Aditya Bakti, 2014).

$$
\text { 1983). }
$$

. Permasalahan Hukum di Indonesia. (Bandung: Alumni, 
Samsul, Inosentius. Pelindungan Konsumen Kemungkinan Penerapan Tanggung Jawab Mutlak. Cetakan pertama. (Jakarta: Universitas Indonesia Fakultas Hukum Pascasarjana, 2004).

Shidarta. Hukum Perlindungan Konsumen Indonesia. Edisi Revisi 2006. (Jakarta: Grasindo, 2006).

Sidabalok, Janus. Hukum Perlindungan Konsumen di Indonesia. (Bandung: Citra Aditya Bakti, 2006).

Soekanto, Soerjono. Pengantar Penelitian Hukum. (Jakarta: Universitas Indonesia, 2006). (Jakarta: UI-Press, 2008).

Pengantar Penelitian Hukum. Cetakan ke-3.

Soekanto, Soerjono dan Sri Mamudji. Penelitian Hukum Normatif Suatu Tinjauan Singkat. (Jakarta: Raja Grafindo Persada, 2009).

Sutedi, Adrian. Tanggung Jawab Produk dalam Hukum Perlindungan Konsumen. Cetakan Pertama. (Jakarta: Ghalia Indonesia, 2008).

Tini Hadaad dalam A.Z. Nasution. Hukum Perlindungan Konsumen Suatu Pengantar. Cetakan ke-2. (Yogyakarta: Diadit Media, 2001).

\section{B. Peraturan Perundang-Undangan}

Indonesia. Kitab Undang-Undang Hukum Perdata [Burgerlijk Wetboek], Tahun 1975, 1981 (Lembaran Negara Republik Indonesia Tahun 1975 Nomor 12).

. Undang-Undang Nomor 8 Tahun 1999 tentang Perlindungan Konsumen.

. Undang-Undang Nomor 36 Tahun 2009 tentang Kesehatan. . Undang-Undang Nomor 18 Tahun 2012 tentang Pangan.

. Peraturan Pemerintah Nomor 69 Tahun 1999 tentang Label dan Iklan Pangan.

\section{Internet}

Faisal M. "Menuntut Perusahaan Rokok Akibat Kecanduan, Mungkinkah?" https://tirto.id/menuntut-perusahaan-rokok-akibatkecanduan-mungkinkah-cF11. diakses 10 April 2018. 


\section{Kamus}

Departemen Pendidikan dan Kebudayaan. Kamus Besar Bahasa Indonesia. Edisi ke-2 (Jakarta: Balai Pustaka, 1995). 